\title{
Capital Structure and Firm Performance: Evidence from Malaysian Public Listed Plantation Companies
}

\author{
Jee Kim Foong, Joanne Ngui Jia En, Jessica Poh Pei Pei, Chan Wai Loon \& Wong Yet \\ Siang \\ Universiti Malaysia Sarawak, Sarawak
}

\begin{abstract}
This paper examines the relationship between capital structure and performance of firms. The study is confined to plantation sector companies in Malaysia and is based on a sample of 39 firms which listed in Bursa Malaysia for the period from 2009 to 2019. This study uses two performance measures which are ROA and ROE as the dependent variable. Besides, the capital structure measures are the short-term debt, long-term debt, total debt and firm growth, which as the independent variables. Size will be the control variable in this study. Moreover, a fixed-effect panel regression analysis has been used to analyse the impact of capital structure on firm performance. The results indicate that firm performance, which is in term of ROA, have an insignificant relationship with short-term debt (STD) and long-term debt (LTD). For the total debt (TD) and growth, there is a significant relationship with ROA. However, for the performance measured by ROE, it has an insignificant relationship with short-term debt (STD), long-term debt (LTD) and total debt (TD). Furthermore, there is a significant relationship between the growth and the performance firms from plantation sector in Malaysia.
\end{abstract}

Keywords: Capital Structure, Firm Performance, Malaysia

\section{INTRODUCTION}

Long-term debt, particular short-term debt, common equity, preferred equity, and retained earnings are all components of a company's capital structure, which are utilised to fund the company's overall operations and growth. Capital structure is one of the most essential effective parameters in the capital markets for determining the value and direction of economic companies (Emamgholipour et al., 2012). Due to the current changing and evolving environment, rating companies, which rely on their capital structure and strategic planning to achieve the goal of "shareholder wealth maximisation," were required to select effective resources in order to achieve the goal of "shareholder wealth maximisation." As a result, determining the greatest mix of financial resources for the company in order to maximise shareholder wealth is one of the most crucial aims that financial manager should address. A sensible financial manager can minimise the firm's cost of capital and raise the corporate value by making precise and timely judgments in order to enhance the firm's performance. As a result, adequate and proper financing and investment will boost the company's worth as well as the wealth of its shareholders. In long run, debt and equity combine to generate a company's financial capital. It can effectively reduce the cost of capital and boost net economic returns, hence increasing the company value, by constructing the ideal capital structure between debt and equity (Awan, Bhatti, Ali, \& Qureshi, 2010). Besides, a company's capital structure is a mix of debt and equity that makes up the sources of corporate assets. The capital structure of a corporation with no debt is solely equity. Furthermore, companies' financin 
resources can be classified into two categories based on their financial policies which are internal and external financial resources. Internal financial resources are typically funded through accumulated earnings from the company's operating activity. However, debt and equity will be available to firms as a source of external financial resources (Emamgholipour et al., 2012). There are three types of decision which are investment, financial, and dividend decisions and all of them have an impact on a company's profitability. However, the focus of this research study will be on financial decisions which involving the company's capital structure. It is mostly used to determine the best financial resource combination and to maximise the firm's worth (Emamgholipour et al., 2012). Moreover, a shift in financing decisions will have a significant impact on investment and dividend decisions (Nimalathasan \& Brabete, 2010). Additionally, capital structure is a crucial financial decision as it is directly linked to a company's risk and return. Any inexperienced capital structure decision can lead to a high cost of capital as well as decreasing the firm's value (A. F. M. Mainul Ahsan et al., 2014). Since the capital structure of each company differs from another, corporate management must determine their own best capital structure in order to maximise the firm's worth.

According to the Modigliani and Miller (1958) theorem, capital structure is irrelevant in determining the firm's value under very restrictive assumptions of a perfect capital market, such as investors' homogeneous expectations, a tax-free economy, and no transaction costs. This argument is then made by modifying the capital structure, the firm's value can be improved due to the tax benefits of debt. To earn money, investors would want to acquire undervalued shares and sell the overvalued shares. When investors take advantage of these arbitrage opportunities, the overvalued shares' price falls while the undervalued shares' price rises until their prices are equal (Salim \& Yadav, 2012). These limiting assumptions, however, do not hold true in the real world. Many academics have added to the rationale for this thesis and its underlying assumptions, demonstrating that capital structure has an impact on a company's value and performance (Ibrahim El-Sayed Ebaid, 2009). The level of leverage in a company's capital structure influences agency conflicts between managers and shareholders by limiting or encouraging managers to act more in the shareholders' best interests. Moreover, it can influence a manager's behaviour and operational decisions, implying that the level of leverage in the capital structure has an impact on business performance (Ibrahim El-Sayed Ebaid, 2009).

This study aims to investigate the relationship between capital structure and firm performance over the period from 2009 to 2019 within Malaysian listed companies using a panel data analysis. This section describes and explains on the context of capital structure on performance of Malaysian companies. For the next session, it will be reviewing on some of the theoretical and empirical evidence concerning the capital structure. Besides, the following section describes the methodology of the research. For the last session, it indicates the empirical results of the empirical analysis as well as a discussion of the conclusions that can be derived from the results.

\section{LITERATURE REVIEW}

\section{Empirical Evidence}

Numerous studies have been conducted on the relationship between capital structure and firm efficiency. Ganiyu, Rodionova, and Samuel (2019) investigated the effect of capital structure on firm success in Nigeria from 1998 to 2015, selecting 115 companies from the Nigerian Stock Exchange. The analysis used a two-step generalised method of moments (GMM) estimation method. The secondary data used in this analysis came from the annual reports of Nigerian publicly traded firms. The findings 
reveal a significant positive relationship between capital structure and firm performance. The capital structure, such as short-term and total leverage ratios, is linked to firm profitability, which is described as return on equity (ROE). The study also discovered that the square term of the short-term leverage ratio and the long-term debt to total capital have a negative relationship with return on equity. Nguyen and Nguyen (2020) investigated the impact of capital structure on performance in Vietnam from 2013 to 2018. The study sample panel comprises 448 non-financial listed companies on the Vietnam Stock Exchange. In this analysis, the generalised least square (GLS) method is used. The ratios of short-term liabilities, long-term liabilities, and total liabilities to total assets are used to estimate capital structure, and firm performance is evaluated by return on equity (ROE), return on assets (ROA), and earnings per share (EPS). Control variables in the analysis include firm size, growth rate, liquidity, and the ratio of fixed assets to total assets. According to the empirical findings, capital structure has a statistically significant negative effect on firm performance. The findings revealed that return on equity and return on assets are negatively linked to short-term debt to total assets, long-term debt to total assets, and total debt on total assets.

A related study by Sahari, Rahim, and Tinggi (2019) looks at the capital structure and firm efficiency in the Malaysian food processing industry. The findings show that all of the variables have a significant impact on firm performance. This study used 450 observations from 45 food processing companies listed on the Bursa Malaysia from 2007 to 2016. The descriptive, correlation, and regression techniques were used in their data analysis. Financial leverage, size, and age are used to measure capital structure, while return on assets is used to measure firm efficiency. In addition, they determine a pooled, set, and random effect model in their research. According to the study, leverage has a significant relationship and is negatively related to firm performance, whereas firm size and age have a significant relationship and are positively related to firm performance. Chadha and Sharma (2015) investigate the effect of capital structure or financial leverage on firm performance over a 10-year span, using data from 422 Indian manufacturing companies listed on the Bombay Stock Exchange (BSE). The appropriate statistical analysis technique, such as the panel data fixed effect regression model, was used in this research. Return on asset, return on equity, and Tobin's Q were chosen as proxies for firm results, while leverage ratio, size, age, tangibility, sales growth, asset turnover, and ownership structure were chosen as proxies for capital structure. The findings show that financial leverage has no effect on key performance indicators like return on assets and Tobin's Q. Financial leverage, on the other hand, has been found to have a negative and substantial association with return on equity. The firm's financial performance is affected by the other independent variable.

Another study on capital structure and firm performance in the Nigerian cement industry was conducted by El-Maude, Ahmad, and Ahmad (2016). The study made use of balanced panel data, which included 20 observations from four companies from 2010 to 2014. The descriptive statistics, correlation, and regression tools are used in the data analysis tool. The performance was measured using return on asset and return on equity. The debt to total asset ratio, which is divided into long-term and short-term debt to total debt ratios, is the study's independent variable, while firm size is the control variable. The results show that short-term and long-term liabilities both have statistically important effects on return on asset and return on equity. Ramadan and Ramadan (2015) investigated the impact of capital structure on the performance of industrial Jordanian companies listed on the Amman Stock Exchange between 2005 and 2013. In their research, they used an unbalanced cross-sectional pooled ordinary least square (OLS) regression model. The sample consisted of 72 publicly traded firms. The long-term debt to total capital ratio, total debt to total capital ratio, and total debt to total assets ratio are all proxies for firm performance, while the long-term debt to total capital ratio, total debt to total capital ratio, and total debt 
to total assets ratio are all proxies for capital structure. According to the findings, the total capital ratio, total debt to total capital ratio, and total debt to total assets ratio all have a negative and statistically significant effect on return on assets.

Nassar (2016) examined the impact of capital structure on the financial performance of Turkish industrial firms using a multivariate regression analysis. The research was conducted on 136 industrial companies listed on the Istanbul Stock Exchange (ISE) over an eight-year period from 2005 to 2012. Firm performance is measured by return on asset, return on equity, and earnings per share, while capital structure is measured by debt ratio. The findings show that capital structure has a negative relationship with firm financial performance. All financial performance variables, such as return on asset, return on equity, and earnings per share, are negatively and significantly correlated with debt ratio. Furthermore, Mouna, Jianmu, Havidz, and Ali (2017) used a panel regression approach to investigate the impact of capital structure on firm performance in Morocco from 2014 to 2016. A total of 53 Moroccan businesses were chosen for the research. Debt ratio (DR) and total debt equity ratio (DER) are the independent variables, return on asset and return on equity are the dependent variables, and size and industry are the control variables. The findings show that while debt ratio and sector have insignificant impact on return on equity, debt equity ratio and scale have a significant impact. Furthermore, the debt ratio has a significant effect on return on asset, while debt to equity, size, and industry have no impact. In short, leverage has a significant negative impact on the firm's profit.

Amin and Jamil (2015) conducted research in Bangladesh on the effect capital structure has on firm performance in the Dhaka Stock Exchange Limited's listed cement market. The study used panel data from 2001 to 2015, and seven different cement sectors were chosen as samples. Short-term debt to total assets and long-term debt to total assets are used to measure capital structure and return on equity (ROE) and return on asset are used to measure performance (ROA). The cement company's size, sales growth, and age were used as control variables in the analysis. The short-term debt to total assets ratio has a substantial positive relationship with firm efficiency as calculated in terms of ROE and ROA, while longterm debt has a negative relationship with firm profitability. Awais, Iqbal, Iqbal, and Khursheed (2016) investigated the impact of capital structure on firm performance from 2004 to 2012. The study used 100 non-financial companies listed on the Karachi Stock Exchange as a sample. Long-term debt to asset, shortterm debt to asset, total debt to assets, firm size, and firm growth are the capital structure measures. Return on assets and equity, earnings per share, and Tobin's Q are the performance measures. The study discovered that all of the performance measures have a statistically significant relationship with long-term debt to asset, short-term debt to asset, and overall debt to asset ratios. Firm size and growth have a positive effect on firm performance, while long-term and short-term debt to asset have a negative impact on the measurement of firm performance.

\section{Theoretical Review}

In this study, there are some theories will be used to explain the relationship between capital structure and firm performance. Modigliani and Miller theory, trade-off theory, pecking order theory, agency cost theory and market timing theory are some of the theories relevant to the determination of capital structure in corporations. Over the years, several academic researchers have attempted to determine empirical evidence to support these theories. The Modigliani and Miller (M\&M) theory was the first to be developed from capital structure. The most fundamental theory for the structure of capital is arguably the theory elaborated by of Modigliani and Miller (1958); Modigliani and Miller (1963). Assuming a zero corporate income tax rate, no transaction costs, and risk-free debt, Modigliani and 
Miller (1958) argue that capital structure is unrelated to firm valuation or that adjusting the capital structure has no effect on the firm's value. Modigliani and Miller published a new research paper in 1963 to correct their previous error by incorporating corporate income tax into the research model. Modigliani and Miller (1963) conclude that the value of firms with more debt in their capital structure is equal to the market value of firms without debt in their capital structure plus what is known as the "tax shield." In conclusion, Modigliani and Miller (1963) demonstrate that capital structure affects firm's market value and that firms can increase firm value by increasing debt levels in their capital structure (Sabin and Miras, 2015). In addition, trade-off theory which addressed by Kraus and Litzenberger (1973) and Jensen and Meckling (1976). This idea refers to how a business funds its capital through debt and equity financing in order to offset costs and benefits. They drew the conclusion that the market value of a company with debt is equal to the value of a company without debt plus the value of the tax shield minus the current value of bankruptcy costs. This means that the tax benefits received from debts would be compensated against losses in the event of bankruptcy. Consequently, trade-off theory predicts that higher-profitability firms would be able to take advantage of more tax benefits by raising leverage without causing financial instability and using a higher proportion of debt financing in their capital structure (Kausar, et al., 2014). In a brief, this principle proposes that there is an ideal capital structure for firms in which the value of tax shelter better compensates for debt-related losses such as financial distress and agency costs.

Another important theory of capital structure which is pecking order theory that explains financing decisions of business managers and financing follows hierarchy. Firms prefer internal to external funding and debt to equity; that is, they first use internal resources such as internal funds and retained earnings, then loans such as debt securities, and eventually equity issued when no more debt can be approached (Myers and Majluf, 1984). Donaldson (1961) developed this theory because of information asymmetry between business owners and external investors. Although owners are well informed of the firm's financial position, external investors are often under-informed, so they are wary of the completeness and truthfulness of the details presented by the business owners. As a result, businesses often face higher costs for external financing. According to the pecking order principle, internal resources will often be preferred to loans, and using internal funds will minimize companies' reliance on external parties, increase financial control, and reduce internal information leakage (Myers and Majluf, 1984). Thus, retained earnings are preferable to outside assets, and debt is preferable to equity for companies in need of external funds. An optimal debt ratio to optimize firm value is not stated in this theory. Changes in the debt ratio result from increased external funding demand as internal funds are completely utilized.

Furthermore, agency cost theory concept was initially developed by Berle and Means (1932), followed by Jensen and Meckling in year 1976. Berle and Means (1932) argued that as large companies' equity ownership diluted, ownership and management become increasingly divided. However, Jensen and Meckling (1976) were the first to specifically model this because of issues concerning the agent's actions against the principal. As a result, agency cost is a cost resulting from a conflict of interest between the principal and the agent (Ahmad, et al., 2012). According to Jensen and Meckling (1976), there is an agency expense in any organization if the managers are not shareholders or owners. Where the shareholders (principal) and manager (agent) do not have a reciprocal expectation on the action taken to maximize shareholder capital, agency cost arises. In a large corporation, there can be hundreds or thousands of shareholders (principals), and ownership of the corporation is distributed among several individuals. Because of the uncertain ownership of management, this form of organization typically has an agency issue. Thus, a manager (agent) will opt to maximize their own interests rather than maximize 
shareholder wealth because if the high-risk project fails, the manager will lose their job, even if the project succeeds and maximizes shareholder wealth. However, the principle-agent problem and the free cash flow problem can be addressed to some degree by increasing the debt amount (Roshan, 2009). High debt encourages managers to invest in lucrative projects that favor shareholder capital to ensure that the business can pay the interest (Berger \& Patti, 2002). As a result, high debt would minimize agency costs and improve firm efficiency (Chinaemerem \& Anthony, 2012).

Moreover, according to market timing theory, the option of debt or equity issuance is determined by the firm's market valuation background (Baker \& Wurgler 2002; Kayhan \& Titman 2007; Myers 1984). Baker and Wurgler (2002) argue that market timing theory better describes corporate capital structure, and that stock price volatility has a direct impact on capital structure. In other words, this theory proposes that capital structure decisions are affected by share price market factors, or that managers base funding decisions on the stock market. Undoubtedly, managers will issue stocks in response to a rise in stock prices or if their stocks are overvalued to capitalize on the situation, and they will typically use leverage in response to a fall in stock prices. The authors reject the existence of an ideal capital structure and consider capital structure formation to be the product of decisions that alter capital structure during company valuation by market value. As a result, there is no concept of optimal capital structure in this theory to optimize firm worth.

\section{METHODOLOGY}

\section{Data and Sample}

The cause-and-effect relationships between variables are concerned with causality. Causal analysis is a study designed to explore causal relationships (Oppewal, 2010). The goal of causal descriptive research is to test the effect of the independent variables on the dependent variable. The relationship between capital structure and firm performance is explained in this research study by the use of causal research. Additionally, the performance of Bursa Malaysia's listed companies will be influenced by capital structure which in term of short-term debt, long-term debt, total debt and firm growth. In addition, secondary data will be used in this research. Secondary data is described as previously collected research data that can be accessed by researchers (Rouse, 2017). There are 39 plantation firms listed on Bursa Malaysia are chosen as the sample for the research. The data are sourced from the Bursa Malaysia Web page and the company's official Web page. The data of 39 plantation companies listed on Bursa Malaysia are collected from the financial statements in the annual reports over a period of 10 years which are from 2009 to 2019. The application of statistical analysis software, Stata 16 had been used in this study to examine the chosen sample of plantation firms listed in Bursa Malaysia. It is a useful tool in analysing the time series econometrics, forecasting model, and test the correlation between the dependent variable and independent variable.

\section{Determinants of variables Variable definition}

This study mainly evaluates the capital structure and performance of plantation firms in Malaysia. For the firm performance, it is measured in term of return on assets (ROA) and return on equity (ROE), however, short term debt (STD), long term debt (LTD), total debt (TD), firm growth is the measurement of capital structure. In addition, firm size will be the control variable in this study. In the subsection, each of the variables will be discussed in detail. 


\section{Dependent Variables}

There are several alternatives in measuring the firm performance which include Return on Assets (ROA), Gross Operating Profit (GOP), Return on Equity (ROE), and Net Profit Margin (NPM). In this study, ROA and ROE have been used as the measurement of dependent variable in this study. It is in line with previous research, Falope and Ajilore (2009) and Sharma and Kumar (2011), which use ROA as the proxy to measure the profitability of firm concerning the capital invested in it by common shareholders, preferred shareholders, and debt financing providers (Warrad, 2015). Return on Assets (ROA) is a calculation of how efficiently a company handles its assets relative to its total assets by assessing how profitable a firm is. The greater the return on asset, the more effective and efficient management is in the utilisation of economic capital. Furthermore, return on assets (ROA) ratio can be calculated by dividing the net profit before taxes by total assets. This ratio calculates a company's operating efficiency based on the profits it generates from its total assets. A high value of return on assets (ROA) indicates that the firm may benefit from assets with a comparatively high value. On the other hand, return on equity (ROE) ratios demonstrate the extent to which organisations efficiently manage their capital (net worth), measuring the profitability of the investment made by the company's capital owners or shareholders (Heikal et al., 2014). According to Warrad (2015), the return on equity (ROE) is a metric that measures the profit per dollar invested by the owner. In this research study, return on equity (ROE) ratio is calculated by dividing net profit before taxes by total shareholders' equity. The rate of return on a shareholder's investment in the company is measured by this ratio. The larger the return on equity (ROE) ratio, the larger the profit growth (Ang, 2001).

\section{Independent Variables}

There are four independent variables that have been used in this study as the proxy to measure the capital structure which include short term debt (STD), long term debt (LTD), total debt (TD), firm growth. Short-term debt, which also known as current liabilities, is a company's debt that is due to be repaid within a year. Short-term mortgage advances, bills payable, compensation, leasing fees, and income taxes payable are all examples of short-term debt. The fast ratio is the most common indicator of short-term liquidity, and it is used to determine a company's credit rating (Corporate Finance Institute, 2020c). Companies that use short-term debts must repeat the cycle of repaying existing debts and borrowing new ones frequently. Besides, short-term debts are subject to market interest rates, leading capital utilisation to be volatile (NGUYEN \& NGUYEN, 2020). In this study, short-term debt (STD) is calculated by the ratio of shortterm debt to total asset. Long-term debt (LTD) is any amount of revolving debt held by a corporation with a maturity of 12 months or more (Corporate Finance Institute, 2020a). It is also known as a non-current liability in the balance sheet. LTD maturities can vary from 12 months to 30 years, and the forms of debt can include bonds, leases, bank loans, and debentures, etc. Additionally, long-term debt in accounting commonly refers to a company's obligations and other commitments that are not payable until one year of the balance sheet data (Averkamp, 2020). For the proxy to measure long-term debt (LTD), it is calculated by the ratio of long-term debt to long-term debt plus equity.

Debt is a risk that a firm may face when involved in business. The leverage ratio provides corporate executives with information about the company's financial health (Leonard, 2019). When the debt of the company is higher and result in a debt ratio with higher than 1, it means that the firm has more amount of debt than assets. Meanwhile, when the debt ratio is smaller than 1, it means that amount of assets is higher than debt (Bragg, 2020). In this research study, total debt (TD) is calculated by dividing the total 
debt with total asset of the firm. Total debt is the sum of all long-term obligations, and it can be seen on the balance sheet of the company. The rate of growth is expressed as a percentage of total assets. Firm growth is a period at which a company has reached the point that it needs to expand and is looking for new ways to increase profits. The company life cycle, market growth patterns, and the owners' ability to create equity capital are all factors that influence business growth (Attract Capital, 2019).

\section{Control Variables}

The control variables are the variable which have strong influenced on the relationship between dependent variables and independent variables. The firm size is taken as the control variable in this study which examining the relationship between capital structure and firm performance. Larger firms with bargaining strength are easily in getting the extended credit term from the suppliers. In contrast, smaller firms might require the pay from their suppliers immediately within a short period of time. Natural logarithm of assets is used as the measurement of the firm size in this study. In addition, many researchers have also use firm size as their control variable such as Deloof (2003), Dong and Su (2010), and Lazaridis and Tryfonidis (2006).

Table 1: Summary of the variables and the formula

\begin{tabular}{|l|c|}
\hline Dependent variables & Formula \\
\hline Return on asset (ROA) & $\frac{\text { Net income }}{\text { Total Assets }}$ \\
\hline Return on equity (ROE) & $\frac{\text { Net income }}{\text { Shareholders Equity }}$ \\
\hline Independent variables & Formula \\
\hline Short term debt (STD) & $\frac{\text { Short term debt }}{\text { Total Asset }}$ \\
\hline Long term debt (LTD) & $\frac{\text { Long term debt }}{\text { Total Asset }}$ \\
\hline Total debt (TD) & $\frac{\text { Total debt }}{\text { Total } \text { Asset }}$ \\
\hline Firm growth (FG) & $\frac{\text { Total asset } t_{t}-\text { Total }_{\text {asset }}(t-1)}{\text { Total asset }}(t-1)$ \\
\hline Control variable & Formula \\
\hline Firm size (FS) & Ln (Total assets) \\
\hline
\end{tabular}

\section{Panel data regression}

Panel data regression model is used to test the hypothesis of this study. Since this study has consisted of more than one independent variables, therefore, the model estimation is shown as follows:

$$
\begin{aligned}
& \mathrm{ROA}=\beta_{0}+\beta_{1}(\mathrm{STD})+\beta_{2}(\mathrm{LTD})+\beta_{3}(\mathrm{TD})+\beta_{4}(\mathrm{FG})+\beta_{5}(\mathrm{FS})+\varepsilon \mathrm{t} \\
& \mathrm{ROE}=\beta_{0}+\beta_{1}(\mathrm{STD})+\beta_{2}(\mathrm{LTD})+\beta_{3}(\mathrm{TD})+\beta_{4}(\mathrm{FG})+\beta_{5}(\mathrm{FS})+\varepsilon \mathrm{t}
\end{aligned}
$$

where: 


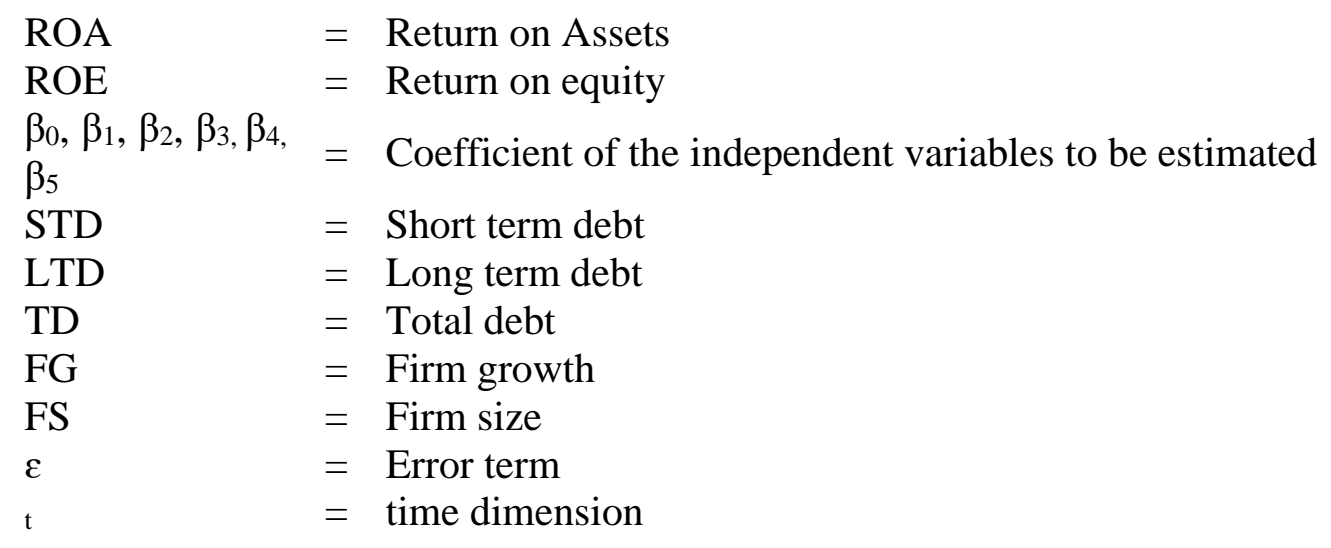

\section{RESULTS AND DISCUSSION}

\section{Descriptive Analysis}

Table 2: Summary of Descriptive Statistics

\begin{tabular}{|c|c|c|c|c|c|}
\hline & Observation & Mean & Minimum & Maximum & Std. Dev. \\
\hline ROA & 429 & 0.0375 & -0.2295 & 0.2797 & 0.0583 \\
\hline ROE & 429 & 0.0433 & -0.6033 & 0.5438 & 0.0840 \\
\hline STD & 429 & 0.1222 & 0.0007 & 0.5830 & 0.1093 \\
\hline LTD & 429 & 0.1668 & 0 & 0.8828 & 0.1201 \\
\hline TD & 429 & 0.2890 & 0.0019 & 0.8454 & 0.1883 \\
\hline GROWTH & 429 & 0.0837 & -0.4480 & 3.6167 & 0.2823 \\
\hline SIZE & 429 & 8.7458 & 5.9744 & 10.3784 & 0.9388 \\
\hline
\end{tabular}

Table above shows the descriptive statistics which include mean, minimum, maximum, and standard deviation of the plantation firm listed in Bursa Malaysia from 2009 to 2019. This study consists of 429 observations. Based on the table above, all the variable used in this study have positive mean. The mean value of ROA and ROE are 0.0375 and 0.0433 , respectively. Besides, the range value of ROA is from -0.2295 to 0.2797 while the range value of ROE is from -0.6033 to 0.5438 . In addition, the mean value of STD, LTD, and TD are $0.1222,0.1668$, and 0.2890 , respectively. In general, total debt of plantation firms in Malaysia accounts for $28.9 \%$, followed by long-term debt ratio with $16.7 \%$, meaning that companies in plantation industry use high level of long-term debt compared to short-term debt. The STD has the minimum value of 0.0007 and the maximum value of 0.5830 whilst the LTD has the minimum value of 0 and the maximum value of 0.8828 . Besides, the TD is at the value of 0.0019 to 0.8454 . Moreover, GROWTH has minimum value of -0.4480 and the maximum value of 3.6167. The SIZE of firm has an average value of 8.7458 and the minimum value and maximum value is between of 5.9744 and 10.3784 . 


\section{Pearson Correlation Analysis}

Table 3: Results of Pearson Correlation Analysis

\begin{tabular}{|c|c|c|c|c|c|c|c|}
\hline & ROA & ROE & STD & LTD & TD & GROWTH & SIZE \\
\hline ROA & 1 & & & & & & \\
\hline ROE & $0.8234 * * *$ & 1 & & & & & \\
\hline STD & $-0.2786^{* * *}$ & $-0.296^{* * *}$ & 1 & & & & \\
\hline LTD & $-0.2492^{* * *}$ & $-0.1566^{* * *}$ & $0.3679^{* * *}$ & 1 & & & \\
\hline TD & $-0.3169^{* * *}$ & $-0.2634^{* * *}$ & $0.7963^{* * *}$ & $0.8042^{* * *}$ & 1 & & \\
\hline GROWTH & $0.1271^{* * *}$ & $0.0892^{*}$ & 0.0307 & 0.0129 & 0.0361 & 1 & \\
\hline SIZE & 0.0073 & $0.1232^{* *}$ & 0.0725 & 0.0464 & 0.0763 & 0.0058 & 1 \\
\hline
\end{tabular}

Note: $* * *, * * *$ indicated respectively the significance at $10 \%, 5 \%$, and $1 \%$

The table above show the Pearson correlation matrix for 39 firms in plantation sector which listed in Bursa Malaysia. The table clearly shows the relationship between independent variable and dependent variable. For the ROA model, the correlation between STD and ROA is negative (-0.2786) and it is significant at $1 \%$ significant level. Besides, the correlation between LTD and ROA is negative with the figure of -0.2492 and it significant at $1 \%$ significant level. There is a negative correlation between TD and ROA with the figure of -0.3169 and it is significant at $1 \%$ significant level. Next, the correlation between GROWTH and ROA is positive relationship and significant at $1 \%$ significant level as well. Moreover, there is another positive correlation (0.0073) between SIZE and ROA and it is insignificant at 1\%, 5\% and $10 \%$ significant level. For the ROE model, there is negative correlation (-0.296) between STD and ROE and it is significant at $1 \%$ significant level. There is another negative relationship between LTD and ROE with the figure of -0.1566 and it significant at $1 \%$ significant level. Furthermore, the relationship between TD and ROE with the figure of -0.2634 and it is significant at $1 \%$ significant level. Moreover, the relationship between GROWTH and ROE is positive (0.0892) and significant at $10 \%$ significant level as well. Lastly, the correlation between SIZE and ROE is positive (0.1232) and it is significant at 5\% and $10 \%$ significant level, respectively.

\section{Breusch Pagan LM Test}

Table 4: Results of Breusch Pagan LM Test

\begin{tabular}{|c|c|c|}
\hline Model & Chi2 & Prob>chi2 \\
\hline ROA & 256.06 & 0.0000 \\
\hline ROE & 216.77 & 0.0000 \\
\hline
\end{tabular}


In this study, Breusch pagan LM test is used to determine whether pooled ordinary least square (OLS) or random effect model is suitable for the study. Therefore, if the probability of the model is less than significant level, the null hypothesis will be rejected. Based on the table above, the probability of both model ROA and ROE is 0.0000 which is less than $1 \%$ significant level, hence, the null hypothesis is rejected. The random effect model is chosen as it is suitable in this test as compared to pooled ordinary least square.

\section{Hausman Test}

Table 5: Results of Hausman Test

\begin{tabular}{|c|c|c|}
\hline Model & Chi2 (5) & Prob>Chi2 \\
\hline ROA & 24.92 & 0.0001 \\
\hline ROE & 23.04 & 0.0003 \\
\hline
\end{tabular}

Hausman test has been used in the study which can help to determine whether fixed effect or random effect model will be the more preferred one. Based on the table above, the probability of both model which in term of ROA and ROE are 0.0001 and 0.0003 . Since the p-value for both models are less than the 5\% significance level, the null hypothesis will be rejected. It can then be concluded that fixed effect model will be chosen in this study.

\section{Panel Regression Model}

Table 6: Result of Panel Data Regression Model

\begin{tabular}{|c|c|c|c|c|c|c|}
\hline \multirow{3}{*}{ Variables } & \multicolumn{6}{|c|}{ Regression Model } \\
\hline & \multicolumn{2}{|c|}{ Pooled OLS } & \multicolumn{2}{|c|}{ Random Effects Model } & \multicolumn{2}{|c|}{ Fixed Effects Model } \\
\hline & ROA & ROE & ROA & ROE & ROA & ROE \\
\hline $\begin{array}{l}\text { Short-term } \\
\text { Debt (STD) }\end{array}$ & $\begin{array}{l}-0.0698 \\
(0.257)\end{array}$ & $\begin{array}{c}-0.2107 \\
\left(0.018^{* *}\right)\end{array}$ & $\begin{array}{l}0.0110 \\
(0.837)\end{array}$ & $\begin{array}{l}-0.1211 \\
(0.130)\end{array}$ & $\begin{array}{l}0.0028 \\
(0.958)\end{array}$ & $\begin{array}{l}-0.1377 \\
(0.089 *)\end{array}$ \\
\hline $\begin{array}{l}\text { Long-term } \\
\text { Debt (LTD) }\end{array}$ & $\begin{array}{c}-0.0374 \\
(0.511) \\
\end{array}$ & $\begin{array}{c}-0.0311 \\
(0.705) \\
\end{array}$ & $\begin{array}{c}-0.0166 \\
(0.731) \\
\end{array}$ & $\begin{array}{l}0.0243 \\
(0.736) \\
\end{array}$ & $\begin{array}{l}0.0005 \\
(0.991) \\
\end{array}$ & $\begin{array}{l}0.0528 \\
(0.462) \\
\end{array}$ \\
\hline $\begin{array}{l}\text { Total Debt } \\
\text { (TD) }\end{array}$ & $\begin{array}{c}-0.0488 \\
(0.383) \\
\end{array}$ & $\begin{array}{c}-0.0106 \\
(0.895) \\
\end{array}$ & $\begin{array}{c}-0.1642 \\
(0.001 * * *)\end{array}$ & $\begin{array}{l}-0.1397 \\
\left(0.067^{*}\right)\end{array}$ & $\begin{array}{c}-0.1822 \\
(0.001 * * *)\end{array}$ & $\begin{array}{l}-0.1469 \\
\left(0.076^{*}\right)\end{array}$ \\
\hline $\begin{array}{l}\text { Firm Growth } \\
\text { (Growth) }\end{array}$ & $\begin{array}{c}0.0284 \\
(0.003 * * *) \\
\end{array}$ & $\begin{array}{c}0.0292 \\
(0.032 * *) \\
\end{array}$ & $\begin{array}{c}0.0312 \\
(0.000 * * *) \\
\end{array}$ & $\begin{array}{c}0.0315 \\
(0.005 * * *) \\
\end{array}$ & $\begin{array}{c}0.0335 \\
(0.000 * * *) \\
\end{array}$ & $\begin{array}{c}0.0347 \\
(0.002 * * *) \\
\end{array}$ \\
\hline $\begin{array}{l}\text { Firm Size } \\
\text { (Size) }\end{array}$ & $\begin{array}{l}0.0019 \\
(0.489) \\
\end{array}$ & $\begin{array}{c}0.0131 \\
(0.001 * * *) \\
\end{array}$ & $\begin{array}{c}-0.0086 \\
(0.149) \\
\end{array}$ & $\begin{array}{l}0.0012 \\
(0.883) \\
\end{array}$ & $\begin{array}{c}-0.0770 \\
(0.000 * * *) \\
\end{array}$ & $\begin{array}{c}-0.0895 \\
(0.000 * * *) \\
\end{array}$ \\
\hline Observations & 429 & 429 & 429 & 429 & 429 & 429 \\
\hline R-squared & 0.1235 & 0.1212 & 0.2064 & 0.1148 & 0.2453 & 0.1504 \\
\hline $\begin{array}{l}\text { Adjusted R- } \\
\text { squared }\end{array}$ & 0.1132 & 0.1108 & & & & \\
\hline F-test & $\begin{array}{c}11.92 \\
(0.0000 * * *)\end{array}$ & $\begin{array}{c}11.67 \\
\left(0.0000^{* * *}\right)\end{array}$ & & & $\begin{array}{c}25.03 \\
(0.0000 * * *)\end{array}$ & $\begin{array}{c}13.63 \\
(0.0000 * * *)\end{array}$ \\
\hline $\begin{array}{l}\text { Wald Chi- } \\
\text { square }\end{array}$ & & & $\begin{array}{c}85.21 \\
(0.0000 * * *) \\
\end{array}$ & $\begin{array}{c}50.11 \\
(0.0000 * * *) \\
\end{array}$ & & \\
\hline
\end{tabular}

Note: Figure in parentheses shows p-values

$*$ Significant at $10 \%$ level; **Significant at $5 \%$ level; ***Significant at $1 \%$ level

Table 6 shows the results of panel data regression model which is used to examine the relationship between capital structure and the performance of firms. Among three of the regression models, Pooled OLS, Random Effects model and Fixed Effects model, we use Fixed Effects model as it is the most appropriate and efficient for this research study. For the performance measured by ROA, the models are 
first tested by using the Breusch-Pagan LM test and the significant result of 256.06 with probability of 0.0000, indicates the Random Effects model and refuse the Pooled OLS model. Then, we performed both the Fixed and Random Effects regressions, and comparing them by using the Hausman test. The tabulated Chi-squared value is 24.92 , with the probability of 0.0001 . As the result, it can be concluded that the significant results of Hausman test is supporting the use of Fixed Effects model. However, by measuring the firm performance in term of ROE, the Breusch-Pagan LM test showed a significant result of 216.77 and probability of 0.0000, indicates the Random Effects model and refuse the Pooled OLS model. Then, we obtained the value of tabulated Chi-squared of 23.04 from Hausman test, with the probability of 0.0003. It is found that the significant results of Hausman test is supporting the use of Fixed Effects model.

\section{Diagnostic Test \\ Multicollinearity Test}

Table 7: Results of Multicollinearity Test

\begin{tabular}{|c|c|}
\hline Variables & VIF \\
\hline TD & 15.75 \\
\hline LTD & 6.66 \\
\hline STD & 6.43 \\
\hline SIZE & 1.01 \\
\hline GROWTH & 1.00 \\
\hline Mean VIF & 6.17 \\
\hline
\end{tabular}

According to Brooks (2008), an implicit assumption occurs when explanatory variables are not related to the other explanatory variables. Multicollinearity refers to the existence of exact or inexact linear relationship among the explanatory variables. According to the assumption of CLRM, there is no exact collinearity between the independent variables. When multicollinearity exists, one independent variable is highly correlated with one or more other independent variables in the same multiple regression equation. Based on the rejection rule, multicollinearity will exist in the model when the mean VIF exceeds 10. Based on Table 7 , the mean VIF is 6.17 , which has not exceeded the value of 10 , means there is no multicollinearity exist in the model.

\section{Autocorrelation Test}

Table 8: Results of Autocorrelation Test

\begin{tabular}{|c|c|c|}
\hline Model & F (1, 38) & Prob> F \\
\hline ROA & 2.517 & 0.1209 \\
\hline ROE & 1.809 & 0.1866 \\
\hline
\end{tabular}

The autocorrelation test has been used to check the issue when the variables are known to be autocorrelated. Autocorrelation occurs when the error term in a time period will depend on the error term of other time periods in a systematic way. The results of autocorrelation have been presented in Table 8. The p-value of the F-test for ROA and ROE model are 0.1209 and 0.1866. Since the both p-value is larger than 0.05 , the null hypothesis will not be rejected at $5 \%$ significance level. It can then be concluded that there is no autocorrelation problem exists in both the ROA and ROE model. 


\section{Heteroskedasticity Test}

Table 9: Results of Heteroskedasticity Test

\begin{tabular}{|c|c|c|}
\hline Model & Chi2(39) & Prob>Chi2 \\
\hline ROA & 1734.22 & 0.0000 \\
\hline ROE & 53726.57 & 0.0000 \\
\hline
\end{tabular}

According to Brooks (2008), the problem of heteroscedasticity occurs if the error terms do not have a constant variance. This means that the error terms have different variance but the mean value is constant within the specific period. Based on the assumption in CLRM, the error term must be homoscedasticity. Table 9 presents the result of heteroscedasticity test. Both the probability of ROA and ROE are 0.0000 which is below 0.05. This means the null hypothesis will be rejected at the $5 \%$ significance level. As the result can figure out that there is heteroscedasticity problem exist in both ROA and ROE model.

\section{Fixed Effect Model with Robust Standard Errors}

Table 10: Result of Fixed Effects Model with Robust Standard Errors

\begin{tabular}{|l|c|c|}
\hline \multirow{2}{*}{ Variables } & \multicolumn{2}{|c|}{ Robust Fixed Effects Model } \\
\cline { 2 - 3 } & ROA & ROE \\
\hline Short-term Debt (STD) & 0.0028 & -0.1377 \\
& $(0.953)$ & $(0.279)$ \\
\hline Long-term Debt (LTD) & 0.0005 & 0.0528 \\
& $(0.986)$ & $(0.548)$ \\
\hline Total Debt (TD) & -0.1822 & -0.1469 \\
& $\left(0.002^{* * *}\right)$ & $(0.176)$ \\
\hline Firm Growth (Growth) & 0.0335 & 0.0347 \\
& $\left(0.001^{* * *}\right)$ & $\left(0.017^{* *}\right)$ \\
\hline Firm Size (Size) & -0.0770 & -0.0895 \\
& $\left(0.000^{* * *}\right)$ & $\left(0.005^{* * *}\right)$ \\
\hline Observation & 429 & 429 \\
\hline R-squared & 0.2453 & 0.1504 \\
\hline F-test & 18.18 & 6.01 \\
& $\left(0.0000^{* * *}\right)$ & $\left(0.0003^{* * *}\right)$ \\
\hline Rho & 0.8138 & 0.7600 \\
\hline
\end{tabular}

Figure in parentheses shows p-values

*Significant at $10 \%$ level; **Significant at $5 \%$ level; ***Significant at $1 \%$ level

The heteroskedasticity test has been run to check whether there is heteroskedasticity problem exists in the model. To correct the model, we have used the remedial measure of robust standard error to correct the model. Table 10 represents the analysis result of Fixed Effects model after the remedial measure of robust standard error. As the performance measured by ROA, the coefficients of STD and LTD are 0.0028 and 0.0005 with p-values of 0.953 and 0.986 respectively. The result indicates insignificant positive relationship with ROA. For the coefficients of TD and Size, there are -0.1822 and -0.0770 with p-values of 0.002 and 0.000 respectively. Both of them has a significant negative relationship with ROA. Besides, the coefficient of Growth is 0.0335 with p-value 0.001 . This result indicates Growth has a significant positive effect on ROA at $1 \%$ significance level. This result stipulate 
that an increase of $1 \%$ in Growth will cause an increase in ROA by $3.35 \%$ with other variables held constant. For the F-test, the F-statistics is 18.18 with the probability of 0.0000 . Result showed that the variables are statistically significant at $1 \%$ significance level. Therefore, it can be concluded that there is at least one variable from STD, LTD, TD, Growth and Size are significantly explaining the firm performance which in term of ROA. Moreover, the $R^{2}(0.2453)$ implies that there are about $24.53 \%$ of the total variation in ROA (dependent variable) explained by the variation in STD, LTD, TD, Growth and Size. Lastly, for the rho which measured the differences across the panel is positive at 0.8138 , indicates all the variables across the panels are positively correlated.

On the other hand, for performance measured by ROE, the coefficients of STD and LTD are 0.1337 and 0.0528 with p-values of 0.279 and 0.548 respectively. The result indicated that STD has insignificant negative relationship with ROE while there is a insignificant positive relationship between LTD and ROE. Furthermore, the coefficients of TD and Growth are -0.1469 and 0.0347 with p-values of 0.176 and 0.017 respectively. The result showed that TD has a insignificant negative relationship with ROE. However, Growth has a significant positive effect on ROE at 5\% level of significance. This result showed that an increase of $1 \%$ in Growth will cause an increase in ROE to the tune of $3.47 \%$. Additionally, the coefficient of Size is -0.0895 with p-value 0.005. This result indicates Growth has a significant negative relationship with ROE at $1 \%$ significance level. Besides, the value of F-statistics is 6.01 with probability of 0.0003 , which indicates that the variables are statistically significant at $1 \%$ significance level. It means that there is at least one variable from STD, LTD, TD, Growth and Size is significantly explaining the performance of firm which measured in ROE. Based on the table, $R^{2}(0.1504)$ implies that there are about $15.04 \%$ of the total variation in ROE (dependent variable) is explained by the variation in STD, LTD, TD, Growth and Size. Overall, rho which measured the differences across the panel is positive at 0.7600 , indicates all the variables across the panels are positively correlated.

\section{Discussion on Major Findings Relationship of capital structure on ROA}

Based on Table 10 above, short-term debt has positive and insignificant impact on return on asset. However, these findings are inconsistent with Maude, Ahmad and Ahmad (2016); Oluchi and Nkechi (2019) who found that there is positive significant relationship between short- term debt with return on asset for firms in Nigeria. Khawaisan (2012), on the other hand, found that the short-term debt significantly negative relationship with return on asset. They stated the reason that negative relationship is explained by the increased cost of debt and strong covenants attach to the use of debt. Apart from that, the result by Ajibola, Wisdom and Qudus (2018) also different from this study which they found that there is negative insignificant relationship between short-term debt and return on asset. Besides, long-term debt has positive and insignificant impact on return on asset. This result consistent by Oluchi and Nkechi (2019) who carried out the similar topic for firms in Nigeria. However, these findings are contrast with Manawaduge, Zoysa, Chowdhury and Chandarakumara (2011), Khan (2012) and Sakr and Bedeir (2019); Ozcan (2019) who revealed that there is a negative significant impact between long-term debt and return on asset. This shows that when there is increase in the debt in the firm's capital structure will be associated with a decrease in return on asset. Next, total-debt ratio has negative and significant impact on return on asset. The significant value indicates that any change on total debt does impose impact on return on asset. This result is consistent with Salim and Yadaz (2012); Sakr and Bedeir (2019); Nguyen and Nyugen (2020). However, the result found by Oluchi and Nkechi (2019) is different from this study as they found that there is negative insignificant relationship between these two variables. Furthermore, growth has positive and significant impact on return on asset. This result is consistent with Salim and Yadav (2012); Awais, Iqbal, Iqbal and Khursheed (2016). This result is inconsistent with 
Manawaduge, Zoysa, Chowdhury and Chandarakumara (2011); Abeywardhana (2016) who found that there is positive relationship but statistically insignificant impact on return on asset. Lastly, size has negative and significant impact on return on asset. However, referring to prior study by Sahari, Rahim and Tinggi (2019), they found there is statistically significant and positive relationship between size and firm performance for food producing firms of Malaysia which is inconsistent with this finding of the study. Similarly, the findings of Pouraghajan, Malekian, Emamgholipour, Lotfollahpour and Bagheri (2012); Dada and Ghazali (2016); Maude, Ahmad and Ahmad (2016) also inconsistent with the findings of this study which they found that the relationship between firm size and return on asset is positive and significant. Another study for Pakistan Firms by Javed, Younas and Imran (2014) who found that there is negative insignificant impact between size with return on asset.

\section{Relationship of capital structure on ROE}

The results in Table 10 show short term debt (STD) have negatively and insignificant impact on return on equity (ROE). The insignificant value indicated that any change in short term debt does not impose impact on ROE. It results show support to the study of Kamran, Rose, Ullah and Matiullah (2016) has negative and insignificant relationship with return on equity in Chemical sector of Pakistan from the year 2010 to 2015. Khan (2012) and Umar, Tanveer, Aslam, and Sajid (2012) also found that short term debt (STD) negatively impacts the firm performance measured by ROE, but the impact was insignificant. However, there is an inconsistent result with the study of Amin and Jamil (2015) and Abor (2005) indicates that significant positive relationship exists between short term debt ratio and return on equity. Besides, this results also show support to Modigliani and Miller (1958) irrelevant theory which state that capital structure is unrelated to firm valuation. Furthermore, long term debt (LTD) has positively and insignificant relationship on return on equity (ROE). The result concludes that increase in the values of variables of capital structure that includes LTD does not influence ROE. This result is similar as the Modigliani and Miller (1958) irrelevant theory. However, this result is inconsistent with the numerous studies such as Nguyen and Nguyen (2020), Le and Phan (2017), Salim and Yadav (2012) and Minh, Tien, and Hoang (2019) which state that there is a negative and significant relationship between long term debt and return on equity.

In addition, there is a negative and insignificant relationship between total debt (TD) and return on equity (ROE). This result is supported by the study of Bokhari and Khan (2013) which found that total debt was found to have a negative impact but was insignificant on return on equity of non-financial sector in Pakistan from 2005 to 2011. This result also is similar as the Modigliani and Miller (1958) irrelevant theory. Hussein, Muhannad, and Mashhoor (2019) also found a negative relation between the use of total debt and ROE, but the impact was insignificant. On the other hand, Ajibola, Wisdom, and Qudus (2018) were inconsistent with the above ones as results concluded a significantly positive effect of total debt ratio on the ROE. Moreover, firm growth has a positively and significant effect on return on equity. This suggest that than an increase in growth, it will result in an increase in ROE (performance). Firm growth is very important for business owners, managers, and investors alike as it provides a reasonably accurate projection of the performance of the business; sales revenue is the main business through which a firm's asset and growth opportunities are converted into cash (Hand, 2005). Thus, a firm with strong growth potential, even with small initial returns, is an attractive target for investors. This result is supported by several studies of Ahmed and Afza (2019), Salim and Yadav (2012), Awais, Iqbal, Iqbal and Khursheed (2016) and Hajisaaid (2020) which stated that there is a significant positive relationship between firm growth and ROE. Lastly, there is a negative and significant relationship between firm size and return on equity. There is a negative impact of size's companies on their 
performance in term of return on equity (ROE), the bigger size of firm, the smaller the profit for shareholders. It results is supported by Maryam, Mohammed, Mohammed, and Muhammad (2020) which stated that size has a negative and significant impact on ROE. Nevertheless, the outcome of the study is contradicted with some findings, which are made by Mouna, Jianmu, Havidz and Ali (2017), Nguyen and Nguyen (2020) and Wassie (2020), they concluded that on the correlation between firm size and return on equity, big companies are more profitable than small companies.

\section{CONCLUSION}

This study has examined the impact of capital structure on firm performance of plantation sector firm which listed in Bursa Malaysia for the period of 2009 to 2019. There are 39 plantation firms has been taken as the sample of this study. Hence, there are a total of 429 observation made. This research was using secondary data from the annual report of the firm and STATA was used in order to get the result of the test. The measurement for capital structure is short-term debt (STD), long-term debt (LTD), total debt (TD) and firm growth (GROWTH) while the measurement used to determine the firm performance were return on asset (ROA) and return on equity (ROE). The control variable used was firm size (SIZE). In this study, the objective was to investigate the relationship between STD, LTD, TD and GROWTH with the firm performance of plantation sector. This research had use Breusch Pagan LM test and Hausman test to select the most appropriate model in this study. After running these tests, this research found that fixed model effect is the best model used in this research. Therefore, this result of this study was all based on fixed effect model. Based on findings, the result showed that there was a positive and insignificant relationship between STD and LTD with ROA while TD and SIZE shows that there is a negative and significant relationship on ROA. In addition, the relationship between GROWTH and ROA was positive and significant. Furthermore, in the model of ROE, the findings of the results found out there was an insignificantly negative relationship between STD and TD with ROE. While LTD having a positive and insignificant relationship with ROE. Besides, GROWTH has a positive and significant relationship with ROE whereas SIZE has a negative and significant relationship with ROE.

As a conclusion, only TD has negative and significant relationship to ROA compared to other STD and LTD. Thus, there are some recommendations for plantation companies in Malaysia. This study concludes that internal funds are the preferred financing method for maximizing profitability. Nevertheless, potential debt avoidance may have a negative impact on the employees working for the organization in plantation sector. In a scenario in which a management need finance for an investment but does not want to incur debt, the reasonable source of funding will be internal funds, which are primarily created by employees. As a result, the manager may put pressure on the employees to raise their workload to create more revenue for the organization. This is socially insufficient since such factors may result in greater stress, dissatisfied employees, and a greater percentage of sick leave. Consequently, if employees are put under pressure and end up quitting or calling in sick, they will no longer be able to create money, which directly contradicts the manager's goal of increasing profitability. Furthermore, firm managers should exercise caution while utilizing debt financing. Before making a capital structure decision, firm managers should examine the influence of debt financing on firm performance. They are assisted in determining the optimal debt level and ensuring that they do not employ an excessive amount of debt in their capital structure. To maximize business performance and shareholder value, business managers must shift their real capital structure to the optimal capital structure level and keep it there as much as possible. This is because the optimum capital structure can meet the requirement of lowering the cost of capital while also lowering the cost of insolvency. 


\section{REFERENCES}

A. F. M. Mainul Ahsan, Md. Afzalur Rahaman, Md. Bokhtiar Hasan, \& Md. Nurul Alam. (2014). Influence of capital structure on firm performance: Evidence from bangladesh. International Journal of Business and Management, 9(5), 184-194.

Abdullah, N. \& Kamaruddin, R. (2018). Determinants of job satisfaction among Malaysian youth working in the oil palm plantation sector. Journal of Agribusiness in Developing and Emerging Economies, 8 (4), 678-692.

Abeywardhana, D. Y. (2016). Impact of capital structure on firm performance: evidence from manufacturing sector SMEs in UK. SSRN Electronic Journal. Retrieved from at https://ssrn.com/abstract=2816499

Ahmad, Z., Abdullah, N. M. H. \& Roslan, S. (2012). Capital structure effect on firm's performance: Focusing on consumers and industrials sectors on Malaysian firms. International Review of Business Research Papers, 8(5), 137 - 155.

Ajibola, A., Wisdom, O. \& Qudus.OL. (2018, August). Capital structure and financial performance of listed manufacturing firms in Nigeria. Journal of Research on International Business and Management 5(1), 81-89.

Amin, S \& Jamil, T. (2015). Capital Structure and Firm Performance: Evidence from Cement Sector of Dhaka Stock Exchange Limited. Journal of Finance and Banking, 13(1), 29-42.

Ang, R. (2001). Buku Pintar Pasar Modal Indonesia. Media Soft Indonesia.

Attract Capital. (2019). Business finance consultant. https://www.attractcapital.com/businessgrowth.html

Averkamp, H. (2020). What is long-term debt? AccountingCoach.Com. https://www.accountingcoach.com/blog/what-is-long-term-debt

Awais, M., Iqbal, W., Iqbal, T. \& Khursheed, A. (2016). Impact Of Capital Structure on The Firm Performance: Comprehensive Study of Karachi Stock Exchange. Sci.Int.(Lahore), 28 (1),501-507.

Awais, M., Iqbal, W., Iqbal, T., \& Khursheed. (2016). Impact of capital structure on the firm performance comprehensive study Of Karachi Stock Exchange. Sci.Int.(Lahore), 28(1), 501-507.

Awan, H. M., Bhatti, M. I., Ali, R., \& Qureshi, A. (2010). How are growth opportunities related to corporate leverage decisions? Investment Management and Financial Innovations, 7(1), 90-97.

Baker, M., \& Wurgler, J. (2002). Market timing and capital structure. Journal of Finance, VII (1), 1-32.

Barlow, H.S. (2018). The Malaysian Plantation Industry: A Brief History to the mid-1980s. Retrieved from http://www.arabis.org/index.php/articles/articles/plantation history/the-

malaysian-plantation-industry-a-brief-history-to-the-mid-1980s.

Berger, A. N. \& Patti, E. B. D. (2002). Capital structure and firm performance: A new approach to testing agency theory and an application to the banking industry. Journal of Banking and Finance, 30(4), 1065-1102.

Berle, A. and Means, G. (1932). The modern corporation and private property. Transaction Publishers: USA.

Chadha, S., \& Sharma, A. K. (2015). Capital Structure and Firm Performance: Empirical Evidence from India. The Journal of Business Perspective, 19(4), 295-302.

Chinaemerem, O. C. \& Anthony, O., 2012. Impact of capital structure on the financial performance of Nigerian firms. Arabian Journal of Business and Management Review, 1(12), 43-61.

Collins. (n.d.). Plantation. from https://www.collinsdictionary.com/dictionary/english/plantation.

$\begin{array}{llllll}\text { Corporate } & \text { Finance } & \text { Institute. } & \text { (2020a). }\end{array}$ https://corporatefinanceinstitute.com/resources/knowledge/finance/long-term-debt-ltd/ 
Corporate Finance Institute. (2020b). Return on equity (ROE). https://corporatefinanceinstitute.com/resources/knowledge/finance/what-is-return-on-equity-roe/

Corporate Finance Institute. (2020c). Short-term debt. https://corporatefinanceinstitute.com/resources/knowledge/finance/short-term-debt/

Courtenay, P. P. (1981). The plantation in Malaysian economic development. Journal of Southeast Asian Studies, 12(2), 329-348.

Dada, A.A. \& Ghazali, Z.B. (2016, August). The impact of capital structure on firm performance: Empirical evidence from Nigeria. IOSR Journal of Economics and Finance, 7(4), 23-30.

Deloof, M. (2003). Does working capital management affect profitability of Belgian firms? Journal of Business Finance \& Accounting, 30(3-4), 573-588.

Donaldson, G. (1961). Corporate debt capacity: A study of corporate debt policy and the determination of corporate debt capacity. Boston: Division of Research, Harvard School of Business Administration.

Dong, H. P., \& Su, J. (2010). The relationship between working capital management and profitability: a Vietnam case. International Research Journal of Finance and Economics, 49, 59-67.

El-Maude, J.G., Ahmad, A.R. \& Ahmad, M.M. (2016). Capital structure and firm performance in the Nigerian Cement Industry. Archives of Business Research, 4(6), 30-44.

Emamgholipour, M., Lotfollahpour, V., Malekian, E., Mohammad Mohammadpour Bagheri, \& Pouraghajan, A. (2012). The relationship between capital structure and firm performance evaluation measures: Evidence from the Tehran stock exchange. International Journal of Business and Commerce, 1(9), 166-181.

Falope, O. I., \& Ajilore, O. T. (2009). Working capital management and corporate profitability: Evidence from panel data analysis of selected quoted companies in Nigeria. Research Journal of Business Management, 3(3), 73-84.

Ganiyu, Y. O., Adepolo, I., Rodionova, Y. \& Samuel, O. L. (2019). Capital Structure and Firm Performance in Nigeria. African Journal of Economic Review, 7(1), 31-56.

Ghafar, M. A. A. \& Har, W. P. (2015). The impact of accounting earnings on stock returns: The case of Malaysia's plantation industry. International Journal of Business and Management, $10(4), 155-165$.

Gim, A. (2019). Plantation companies brace for challenges ahead. 27 Group. Retrieved from https://27.group/\%EF\%BB\%BFplantation-companies-brace-for-challenges-ahead/

Heikal, M., Khaddafi, M., \& Ummah, A. (2014). Influence Analysis of Return on Assets (ROA), Return on Equity (ROE), Net Profit Margin (NPM), Debt to Equity Ratio (DER), and current ratio (CR), Against Corporate Profit Growth In Automotive In Indonesia Stock Exchange. International Journal of Academic Research in Business and Social Sciences, 4(12), 101-114.

Ho, Arison Sel Chuan. (2013). Internationalization and capital structures empirical evidence: from Malaysia public listed manufacturing firms. (Master's thesis). University of Malaya.

Ibrahim El-Sayed Ebaid. (2009). The impact of capital-structure choice on firm performance: Evidence from Egypt. The Journal of Risk Finance, 10(5), 477-487.

Javed, T., Younas, W. \& Imran, M. (2014, September). Impact of capital structure on firm performance: Evidence from Pakistani Firms. International Journal of Academic Research in Economics and Management Sciences, 3(5) ,2226-3624

Jensen, M. C. \& Meckling, W. H. (1976). Theory of the firm: Managerial behaviour, agency costs and ownership structure. Journal of Financial Economics, 3, 305- 360.

Kaliyadan,F., \& Kulkarni, V. (2019). Types of variables, descriptive statistics, and sample size. PubMed Central (PMC). Retrived from https://www.ncbi.nlm.nih.gov/pmc/articles/PMC6362742/

Kausar, A., Nazir, M. S. \& Butt, H. A. (2014). Capital structure and firm value: Empirical evidence from Pakistan. Asian Journal of Research in Economics and Finance, 1(1), 11-22. 
Kayhan, A., \& Titman, S. (2007). Firms' histories and their capital structures. Journal of Financial Economics, 83(1), 1-32.

Kenton, W. (2020). Multicollinearity. Retrieved from https://www.investopedia.com/terms/m/multicollinearity.asp

Khan, A, G. (2012). The relationship of capital structure decisions with firm performance: A study of the engineering sector of Pakistan. International of Journal of Accounting and Financial Reporting, 2(1), 2162-3082.

Laziridis, I., \& Tryfonidis, D. (2006). The relationships between working capital management and profitability of listed companies in the Athens stock exchange. Journal of Financial Management and Analysis, 19(1), 26-35.

Leonard, K. (2019). How to determine a company's total debt on a balance sheet. Small Business Chron.Com. https://smallbusiness.chron.com/determine-companys-total-debt-balance-sheet42435.html

Mainzer, R. (2018, August 15). The effect of a preliminary Hausman test on confidence intervals. Bull. Aust. Math. Soc. 98, 518-519.

Manawaduge,A., Zoysa, A.D., Chowdhury,K.\& Chandarakumara,A. (2011). Capital structure and firm performance in emerging economies: An Empirical analysis of Sri Lankan Firms. Corporate Ownership and Control, 8(4).

Modigliani, F. \& Miller, M. H. (1963). Income taxes and the cost of capital: A correction. The American Economic Review, 53(3), 433-443.

Modigliani, F., \& Miller, M. H. (1958). The cost of capital, corporation finance and the theory of investment. The American Economic Review, 48(3), 261-297.

Mouna, A., Jianmu, Y, Havidz, S. A. H. \& Ali, H. (2017). The impact of capital structure on Firm's performance in Morocco. International Journal of Application or Innovation in Engineering \& Management, 6(10), 2319-4847.

Munawar, A. (2018). The effect of leverage, dividend policy, effectiveness, efficiency, and firm size on firm value in plantation companies listed on IDX. International Journal of Science and Research (IJSR), 8(10), 244-252.

Myers, \& Majluf. (1984). Corporate financing and investment decisions when firms have information that investors do not have. Journal of Financial Economics, 13, 187-221.

Myers, S. (1984). The capital structure puzzle. Journal of Finance, 39(3), 575-592.

Nassar, S. (2016). The impact of capital structure on Financial Performance of the firms: Evidence from Borsa Istanbul. Journal of Business \& Financial Affairs, 5(2), 2167-0234.

Nguyen, H. A., \& Nguyen, T. H. (2020, March 6). The Impact of Capital Structure on Firm Performance: Evidence from Vietnam. Journal of Asian Finance, Economics and Business, 7(4), 97- 105.

Nguyen, T.H. \& Nguyen, H. A. (2020). Capital structure and firm performance of non-financial listed companies: Cross-sector empirical evidence from Vietnam. Accounting, 6, 137-150.

Nimalathasan, B., \& Brabete, V. (2010). Capital structure and its impact on profitability: A study of listed manufacturing companies in Sri Lanka. Young Economists Journal/Revista Tinerilor Economisti, 8(15), 7-16.

Oluchi,A. \& Nekchi,U. (2019, July). Effects of capital structure on corporate performance of healthcare sector in Nigeria. International Journal of Research and Innovation in Social Science, 3(7), 24546186.

Oppewal, H. (2010). Causal Research. Wiley International Encyclopedia of Marketing, 1-9. Retrieved from https://doi.org/10.1002/9781444316568.wiem02001

Ozcan, I.C. (2019). Capital structure and firm performance: Evidence from the airport industry. European Journal of Transport and Infrastructure Research, 19(3). 
Paminto, A., Setyadi, D. \& Sinaga, J. (2016). The effect of capital structure, firm growth and dividend policy on profitability and firm value of the oil palm plantation companies in Indonesia. European Journal of Business and Management, 8(33), 123-134.

Pouraghajan,A., Malekian,E., Emamgholipour, M., Lotfollahpour, V \& Bagheri, M.M. (2012). The relationship between capital structure and firm performance evaluation measures: Evidence from the Tehran Stock Exchange. International Journal of Business and Commerce, 1(9), 166-181.

Price, James H., \& Murna, P. (2004). Methodological wishes for the next decade and how to make wishes come true. Journal of Management Studies, 15(1), 66-67.

Ramadan, Z. S., \& Ramadan I. Z. (2015). Capital structure and firm's performance of Jordanian manufacturing sector. International Journal of Economics and Finance, 7(6), 1916-9728.

Roshan, B. (2009). Capital structure and ownership structure: A review of literature. The Journal of Online Education, 1-8.

Rouse, M. (2017). Secondary data. Retrieved from https://www.google.com/amp/s/whatis.techtarget.com/definition/secondarydata\%3famp $=1$

Sabin, D. \& Miras, H. (2015). Debt level and firm performance: A study on low-cap firms listed on the Kuala Lumpur stock exchange. International Journal of Accounting, Business and Management, 1(1), 1-17.

Sahari, S., Rahim, N.A. \& Tinggi, M. (2019). Capital structure and firm performance: Evidence from food processing industry in Malaysia. The Journal of Social Sciences Research, 5 (2). 317-324.

Sakr, A \& Bedeir, A. (2019). Impact of capital structure on firm's performance: focusing on non -financial listed Egyptian Firms. International Journal of Financial Research, 10(6), 1923-4023.

Salim, M., \& Yadav, R. (2012). Capital structure and firm performance: Evidence from Malaysian Listed Companies. Procedia - Social and Behavioral Sciences, 65, 156-166.

Senunyeme, E. K. (n.d.). Business research methods. Retrieved June 6, 2021, from http://www.authorstream.com/Presentation/benjikenney-1581921-business-research-methods/

Sharma, A. K., \& Kumar, S. (2011). Effect of working capital management on firm profitability: Empirical evidence from India. Global Business Review, 12(1), 159-173.

Smith, T. (2020). Autocorrelation. Retrieved from https://www.investopedia.com/terms/a/autocorrelation.asp

Statistics. (2020). Hausman Test for Endogeneity (Hausman Specification Test). Statistics How To. Retrieved from https://www.statisticshowto.com/hausman-test/

Stephanie. (2016). What is serial correlation/ autocorrelation? Retrieved from https://www.statisticshowto.com/serial-correlation-autocorrelation/

Steven Bragg. (2020). Debt ratios. Accounting Tools. Retrieved from https://www.accountingtools.com/articles/debt-ratios.html

Trisha. (n.d.). Concept and features of optimal capital structure. Retrieved from https://www.yourarticlelibrary.com/financial-management/capital-structure/concept-andfeatures-of-optimal-capital-structure/44035

Warrad. L. (2015). Return on asset and return on equity effects of net operating cycle: Jordanian study. Research Journal of Finance and Accounting, 6(14), 89-95.

Zach (2020). The Breusch-pagan test: Definition \& example. Statology. Retrieved from https://www.statology.org/breusch-pagan-test/ 